\title{
Role of upper respiratory tract in COVID-19 patient cases
}

Роля на горните дихателни пътища при COVID-19

\author{
Julian Hadzhiev, MD, PhD \\ Department and clinics of ENT diseases, Medical faculty, Medical university - Sofia, \\ University hospital "Tsaritsa Joanna \\ д-р Юлиян Хаджиев, д.м. \\ Катедра и Клиника по УНГ болести, факултет „Медицина“, Медицински университет - София, \\ УМБАЛ „Царица Йоанна-ИСУЛ“ - ЕАД
}

I n the month of December 2019 in Wuhan, China for the first time a series of cases of an atypical pneumonia caused by a new type of coronavirus were reported (21). The disease was called COVID-19.

COVID-19 is a disease which mainly causes high body temperature, coughing, shortness of breath, myalgia and general malaise. These symptoms are typical for the respiratory system and demonstrate an acute respiratory distress (14). According to the American Academy of Otolaryngology - Head and Neck Surgery anosmia and dysgeusia should be added to the symptoms of COVID-19 (19).

The cause of the disease is a virus - SARS-CoV-2 (severe acute respiratory syndrome coronavirus 2 ) (15).

SARS-CoV-2 is a single-stranded RNA virus, member of the genus Betacoronavirus (16). Its phylogenetic analysis shows that there is a $98,7 \%$ similarity with the coronavirus in bats from the Rhinolophus genus. The evolutionary analysis demonstrates that SARS-CoV-2 is a novel coronavirus passed from animals to humans (17). It is believed that the transition is carried out through an intermediate host - pangolin (18). After that, the spread among humans started. Transmission of the infection is accomplished through airborne way, close contact and contaminated surfaces. Virus
П рез месец декември 2019 година в град Ухан (Китай) за първи път се появява съобщение за множество случаи на атипична пневмония, причинена от нов корона вирус (21). Това заболяване е наречено COVID-19.

COVID-19 е болест, която основно протича с висока температура, кашлица, задух, миалгия и общо неразположение. Това са симптоми от страна на дихателната система, които демонстрират остро респираторно страдание (14). Според American Academy of Otolaryngology - Head and Neck Surgery аносмия и дисгевзия трябва да бъдат добавени към симптомите на COVID-19 (19).

Причинител на заболяването е SARS-CoV-2 (severe acute respiratory syndrome coronavirus 2) (15).

SARS-CoV-2 е едноверижен РНК вирус, който принадлежи към генус Betacoronavirus (16). Филогенетичният му анализ показва 98,7\% сходство с коронавирус при прилепи от род Rhinolophus. Еволюционният анализ демонстри$\mathrm{pa}$, че SARS-CoV-2 е нов корона вирус, който е преминал от животните към хората (17). Смята се, че този преход се е осъществил чрез междинен гостоприемник - панголин (люспеник) (18). След това е започнало и разпространение между хората. Предаването на инфекцията се извършва по въздушно-капков път, близък контакт и 
enters human organism through the mucosa of the respiratory tract.

Angiotensin-converting enzyme 2 (ACE2) acts as a receptor for SARS-CoV-2 (7). ACE2 is an enzyme which converts angiotensin II into angiotensin (1-7) (4). ACE2 is a membrane-attached aminopeptidase found in the endothelium of blood vessels, kidneys, heart, small intestine and testicles $(1,2,3)$. Significant gene expression of ACE2 is proven in alveolar epithelium cells type II (6). The presence of ACE2 in the nasal and bronchial epithelium secretion is proven as well (5). According to different pieces of research related to all parts of the respiratory tract, ACE2 is mainly expressed in the nasal secretory and ciliary type of cells. It is likely that this expression of the viral receptors in the upper respiratory tract is connected with and corresponding to the viral transmission. At the moment scientists have studied the expression of viral receptor genes in other coronaviruses and influenza viruses. Investigations are done for ANPEP in HCoV-22944, DPP4 - used by MERS-CoV45, enzymes ST6GAL1 and ST3GAL4, important for the influenza viruses (8, $9,10)$. Important here is the fact that expression of their receptors coincides with the viral transmission as far as R0 is concerned (basic reproduction number). R0 shows the number of people that get infected by one infected person. It is established that more viral receptors in the upper respiratory tract is observed in viruses with higher R0. For instance, for SARS-CoV/SARS-CoV-2: R0 $\sim 1.4-5.0$, for the influenza virus: R0 1.347 (11, 12). On the other hand, there is a clear contrast in terms of DPP4 distribution, receptor for MERS$\mathrm{CoV}$. MERS-CoV is a human coronavirus with a low ability for transmission ( $\mathrm{R} 0 \sim 0.3-0.8$ ). There, receptor distribution is mainly in the lower respiratory tract and the pulmonary parenchyma (13).

It is likely that viral transmission is connected with receptor distribution in the respiratory tracts. Due to the high receptor expression in the nasal cells we can suppose that these cells play an important role during the initial infection and are a possible reservoir for dissemination for the individual and between people. Taking facts into account until this moment, we can confirm, with high probability that nasal mucosa is of extreme importance for the transmission of the virus. Higher levels of the viral чрез контаминирани повърхности. Входна врата е лигавицата на дихателните пътища.

Angiotensin-converting enzyme 2 (ACE2) служи за рецептор на SARS-CoV-2 (7). ACE2 е ензим, който конвертира ангиотензин II в ангиотензин (1-7) (4). ACE2 е мембранно-свързана аминопептидаза, която се установява в ендотела на кръвоносните съдове, бъбреците, сърцето, тънките черва и тестисите $(1,2,3)$. Значителна е генната експресия на ACE2 в алвеоларните епителни клетки тип II (6). Също така доказано е наличието на ACE2 в назалния и бронхиалния епител (5). Според различни проучвания на всички отдели на респираторния тракт ACE2 е с най-висока експресия в назалните секреторни и назалните ресничести клетки. Твърде е вероятно тази голяма експресия на вирусни рецептори в горните дихателни пътища да съответства на вирусната трансмисия. Към момента е проучена експресията на вирусни рецепторни гени при други корона вируси и при грипните вируси. Изследвани са съответно ANPEP при $\mathrm{HCoV}$ 22944, DPP4-използван от MERS-CoV45, ензимите ST6GAL1 и ST3GAL4, които имат значение при грипните вируси $(8,9,10)$. Важното тук e, че експресията на техните рецептори съвпада с вирусната трансмисия, що се отнася до R0 (basic reproduction number). R0 отразява броя на инфектираните хора от един инфектиран човек. Установява се, че по-голямото разпространение на рецептори в ГДП (горните дихателни пътища) се наблюдава при вируси с по-голям R0. Например при SARS-CoV/SARS-CoV-2: R0 $\sim 1.4-5.0$, при грипния вирус: R0 1.347 $(11,12)$. От друга страна, съществува ясно изразен контраст по отношение разпределението на DPP4, рецептора на MERS-CoV. MERS-CoV е човешки коронавирус с ниска способност за трансмисия (R0 0.3-0.8). При него разпределението на рецепторите е основно към долните дихателни пьтища и белодробния паренхим (13).

Твърде вероятно е вирусната трансмисия да е свързана с разпределението на рецепторите в дихателните пътища. Поради високата експресия на рецептори в назалните клетки можем да предположим, че тези клетки имат важна роля при първоначалната инфекция и са възможен резервоар за дисеминация както при отделния човек, така и между хората. Взимайки предвид фактите до момента, с голяма вероятност можем да потвърдим, че носната лигавица има 
load are proven when investigating nasal in comparison with throat samples. As pathologic changes are observed in both halves of the lungs, this suggests viral dissemination after the initial infection (21). It is possible that this dissemination towards the lungs occurs because of the initial infection in the nasal mucosa. Probably, after the replication of the virus in the nasal cells, viral particles could reach pulmonary parenchyma where they cause severe changes. In patients who died from COVID19, pathohistologically, severe diffuse alveolar changes were observed, which corresponds to the acute respiratory distress syndrome (ARDS) (22). The presence of ACE2 in the cells of the conjunctiva suggests distribution towards the respiratory tract through the nasolacrimal canal (20).

Attaching to and entering into the cells of the coronaviruses is determined by the virus spike(S) protein. Its $\mathrm{S} 1$ subunit connects him to the receptor, and the S2 subunit guides the process of priming and cutting of the S-protein which allows the merging of the viral and cell membranes. The priming process is delivered by cell proteases. SARS-CoV utilizes the cell serine protease TMPRSS2 (23). SARS-CoV-2 also could use TMPRSS2 for the $\mathrm{S}$ protein priming. Hence, the spread of SARS$\mathrm{CoV}-2$ also depends on the activity of TMPRSS2. TMPRSS2 is a factor of the host cell which is of great importance for the spread of some clinically important viruses, including Type A Influenza viruses and coronaviruses $(23,24,25,26)$. It is found out that rabbit serums against the $\mathrm{S} 1$ subunit lower SARS-S and SARS-2-S entering of the cell with high effectivity as inhibiting the SARS-S entering is more effective. Thus, antibody responses towards SARS-S during infection or vaccination may provide some kind of protection against infection with SARS-CoV-2.

Currently, there are still many unknowns for SARSCOV-2 and COVID-19. For sure, upper respiratory tracts are of great importance for the epidemiology of the viral infection and the course of the disease. изключително важно значение за трансмисията на вируса. По-високи нива на вирусния товар са установени при изследването на носни проби в сравнение с гърлени проби. Тъй като патологични промени се наблюдават и в двете половини на белия дроб, това предполага вирусна дисеминация след първоначално инфектиране (21). Възможно е тази дисеминация към белия дроб да настьпва от пьрвоначалната инфекция в назалната мукоза. Вероятно е след репликацията на вируса в носните клетки вирусните частици да достигат до белия дроб, където да предизвикат тежки изменения. При пациенти, починали от COVID-19, патохистологично са установяват тежки, дифузни алвеоларни изменения, които съответстват на acute respiratory distress syndrome (ARDS) (22).

Наличието на ACE2 в клетките на конюнктивата предполага разпространението към дихателните пътища през назолакрималния канал (20). Прикрепването и навлизането на коронавирусите в клетките се определя от вирусния (S) spike протеин. Неговата S1 субединица го свързва към рецептора, а S2 субединицата ръководи процеса на праймиране и срязване на $\mathrm{S}$ протеина, което позволява сливането на вирусните и клетъчните мембрани. Праймирането се осъществява посредством клетьчни протеази. SARS-CoV използва клетъчната серинова протеаза TMPRSS2 (23). SARS-CoV-2 също може да използва TMPRSS2 за S протеиново праймиране. Следователно разпространението на SARS-CoV-2 също зависи и от активността на TMPRSS2. TMPRSS2 е фактор на клетката гостоприемник, който е изключително важен за разпространението на няколко клинично значими вируса, включително вируси на грип А и коронавируси $(23,24,25,26)$. Установено е, че заешки серуми срещу S1 субединица на SARS-S намаляват както SARS-S-, така и SARS-2-S-предизвиканото навлизане с висока ефективност, като инхибирането на SARS-S-предизвиканото навлизане е по-ефективно. По този начин отговорите на антителата срещу SARS-S по време на инфекция или ваксинация могат да осигурят известна степен на защита срещу инфекция със SARS-CoV-2.

Към настоящия момент съществуват все още много неизвестни за SARS-COV-2 и COVID-19. Със сигурност ГДП са от съществено значение за епидемиологията на вирусната инфекция и за 
Nasal mucosa plays an important role for the distribution of the virus for the individual and for the general distribution in the human population. Future investigations in the field are required. They will determine the specific mechanisms of interactions between the mucosa of the upper respiratory tracts and the virus. протичането на заболяването. Носната лигавица има важно значение както за разпространението на вируса в организма на отделния човек, така и за разпространението между хората. Необходими са бъдещи проучвания по въпроса, които да установят по-подробно специфичните механизми на взаимодействие между лигавицата на горните дихателни пьтища и вируса.

\section{References:}

1. Donoghue, M., F. Hsieh, E. Baronas, K. Godbout, M. Gosselin, N. Stagliano, M. Donovan, B. Woolf, K. Robison, R. Jeyaseelan, R. E. Breitbart, and S. Acton.2000. A novel angiotensin-converting enzyme-related carboxypeptidase (ACE2) converts angiotensin I to angiotensin 1-9. Circ. Res. 87:e1-e9.p

2. Hamming, I., W. Timens, M. L. Bulthuis, A. T. Lely, G. J. Navis, and H. van Goor.2004. Tissue distribution of ACE2 protein, the functional receptor for SARS coronavirus. A first step in understanding SARS pathogenesis. J. Pathol. 203:631-637.

3. Harmer, D., M. Gilbert, R. Borman, and K. L. Clark.2002. Quantitative mRNA expression profiling of ACE 2, a novel homologue of angiotensin converting enzyme. FEBS Lett. 532:107-110.

4. Turner, A. J., J. A. Hiscox, and N. M. Hooper.2004. ACE2: from vasopeptidase to SARS virus receptor. Trends Pharmacol. Sci. 25:291-294.

5. Bertram, S. et al. Influenza and SARS-coronavirus activating proteases TMPRSS2 and HAT are expressed at multiple sites in human respiratory and gastrointestinal tracts. PloS ONE 7, e35876 (2012).

6. Qi, F., Qian, S., Zhang, S. \& Zhang, Z. Single cell RNA sequencing of 13 human tissues identify cell types and receptors of human coronaviruses. Biochem. Biophys. Res. Commun.(2020)

7. Mannan Baig A., Khaleeq A., Ali U., Syeda H. Evidence of the COVID-19 virus targeting the CNS: tissue distribution, host-virus interaction, and proposed neurotropic mechanisms. ACS Chem Nerosci. 2020;11:995-998.

8. Yeager, C. L. et al. Human aminopeptidase $\mathrm{N}$ is a receptor for human coronavirus 229E. Nature 357, 420-422 (1992).

9. Raj, V. S. et al. Dipeptidyl peptidase 4 is a functional receptor for the emerging human coronavirus-EMC. Nature 495, 251-254 (2013).

10. Broszeit, F. et al. N-glycolylneuraminic acid as a receptor for influenza A viruses. Cell Rep. 27, 3284-3294 (2019).

11. Riou, J. \& Althaus, C. L. Pattern of early human-to-human transmission of Wuhan 2019 novel coronavirus (2019-nCoV), December 2019 to January 2020. Euro Surveill. 25, 2000058 (2020).

12. Coburn, B. J., Wagner, B. G. \& Blower, S. Modeling influenza epidemics and pandemics: insights into the future of swine flu (H1N1). BMC Med. 7, 30 (2009).

13. Kucharski, A. J. \& Althaus, C. L. The role of superspreading in Middle East respiratory syndrome coronavirus (MERS-CoV) transmission. Euro Surveill. 20, 14-18 (2015).

14. Huang C, Wang Y, Li X, Ren L, Zhao J, Hu Y, Zhang L, Fan G, Xu J, Gu X. Clinical features of patients infected with 2019 novel coronavirus in Wuhan. China. Lancet. 2020;

15. Horton R. Offline: 2019-nCoV outbreak—early lessons. Lancet. 2020;395(10221):322.

16. Chan J.F., Kok K.H., Zhu Z., Chu H., To K.K., Yuan S. Genomic characterization of the 2019 novel human-pathogenic coronavirus isolated from a patient with atypical pneumonia after visiting Wuhan. Emerg Microbes Infect. 2020;9:221-236.

17. Chen L., Liu W., Zhang Q., Xu K., Ye G., Wu W. RNA based mNGS approach identifies a novel human coronavirus from two individual pneumonia cases in 2019 Wuhan outbreak. Emerg Microbes Infect. 2020;9:313-319.

18. Liu, P., Chen, W. \& Chen, J.-P. Viruses 11, 979 (2019).

19. https://www.entnet.org/content/aao-hns-anosmia-hyposmia-and-dysgeusia-symptoms-coronavirus-disease accessed March 25 th 2020.

20. Guan, W.-J. et al. Clinical characteristics of coronavirus disease 2019 in China. N. Engl. J. Med.(2020)

21. Chen, N., et al. Epidemiological and clinical characteristics of 99 cases of 2019 novel coronavirus pneumonia in Wuhan, China: a descriptive study. Lancet 395, 507-513 (2020).

22. Xu, Z., et al. Pathological findings of COVID-19 associated with acute respiratory distress syndrome. The Lancet. Respiratory medicine (2020).

23. Glowacka, I., Bertram, S., Mu“ 1ler, M.A., Allen, P., Soilleux, E., Pfefferle, S., Stef-fen, I., Tsegaye, T.S., He, Y., Gnirss, K., et al. (2011). Evidence that TMPRSS2 activates the severe acute respiratory syndrome coronavirus spike protein for membrane fusion and reduces viral control by the humoral immune response. J. Virol. 85, 4122-4134.

24. Gierer, S., Bertram, S., Kaup, F., Wrensch, F., Heurich, A., Kra“ mer-Ku” hl, A., Welsch, K., Winkler, M., Meyer, B., Drosten, C., et al. (2013). The spike protein of the emerging betacoronavirus EMC uses a novel coronavirus receptor for entry, can be activated by TMPRSS2, and is targeted by neutralizing anti- bodies. J. Virol. 87, 5502-5511.

25. Iwata-Yoshikawa, N., Okamura, T., Shimizu, Y., Hasegawa, H., Takeda, M., and Nagata, N. (2019). TMPRSS2 Contributes to Virus Spread and Immunopa- thology in the Airways of Murine Models after Coronavirus Infection. J. Virol.

26. Matsuyama, S., Nagata, N., Shirato, K., Kawase, M., Takeda, M., and Taguchi, F. (2010). Efficient activation of the severe acute respiratory syndrome corona- virus spike protein by the transmembrane protease TMPRSS2. J. Virol. 84, 12658-12664. 